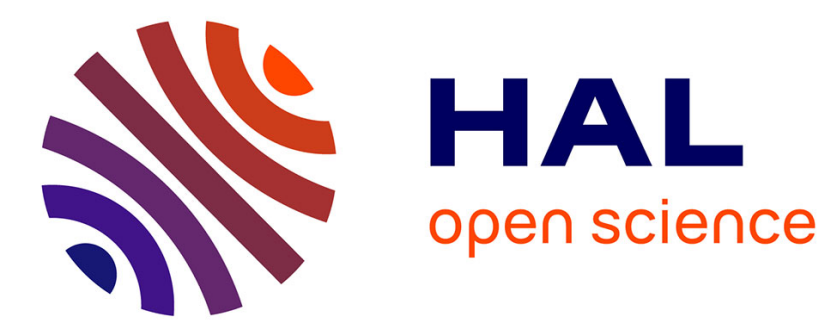

\title{
AlPO-ERI, an aluminophosphate with the ERI framework topology: characterization and structure of the as-made and calcined rehydrated forms
}

\author{
A. Tuel, C. Lorentz, Volker Gramlich, Christian Baerlocher
}

\section{- To cite this version:}

A. Tuel, C. Lorentz, Volker Gramlich, Christian Baerlocher. AlPO-ERI, an aluminophosphate with the ERI framework topology: characterization and structure of the as-made and calcined rehydrated forms. Comptes Rendus. Chimie, 2005, 8 (3-4), pp.531-540. 10.1016/j.crci.2004.11.012 . hal-00012768

\author{
HAL Id: hal-00012768 \\ https://hal.science/hal-00012768
}

Submitted on 26 Oct 2021

HAL is a multi-disciplinary open access archive for the deposit and dissemination of scientific research documents, whether they are published or not. The documents may come from teaching and research institutions in France or abroad, or from public or private research centers.
L'archive ouverte pluridisciplinaire HAL, est destinée au dépôt et à la diffusion de documents scientifiques de niveau recherche, publiés ou non, émanant des établissements d'enseignement et de recherche français ou étrangers, des laboratoires publics ou privés. 


\title{
AlPO-ERI, an aluminophosphate with the ERI framework topology: characterization and structure of the as-made and calcined rehydrated forms
}

\author{
Alain Tuel ${ }^{\mathrm{a}, *}$, Chantal Lorentz ${ }^{\mathrm{a}}$, Volker Gramlich ${ }^{\mathrm{b}}$, Christian Baerlocher ${ }^{\mathrm{b}}$ \\ ${ }^{a}$ Institut de recherches sur la catalyse, CNRS, 2, avenue Albert-Einstein, 69626 Villeurbanne cedex, France \\ ${ }^{\mathrm{b}}$ Laboratory for Crystallography, ETH Zentrum, CH 8092 Zürich, Switzerland
}

\begin{abstract}
An aluminophosphate with the ERI framework topology, further denoted AlPO-ERI, has been synthesized in the presence of $N, N, N^{\prime}, N^{\prime}$-tetramethyl-1,6-hexanediamine and its structure was solved by single crystal X-ray diffraction. It crystallizes in the monoclinic space group $P 2(1)$ (No. 4) with $a=13.163(14) \AA, b=14.793(15) \AA$, $c=13.215(14) \AA, \beta=119.74(8)^{\circ}$. As compared to similar materials prepared with piperidine as template, extraframework hydroxyl groups are locally ordered in the structure. After calcination and rehydration, the aluminophosphate remains monoclinic and crystallizes in space group $P 2(1) / n$ (No. 14) with $a=13.283(17) \AA, b=14.910(14) \AA, c=22.76(3) \AA$ and $\beta=90.19(10)^{\circ}$. Both the as made and calcined rehydrated forms of AlPO-ERI have been characterized by multidimensional solid state NMR.
\end{abstract}

Keywords: Aluminophosphate; $\mathrm{AlPO}_{4}-17$; Erionite; Synthesis; Structure; Two-dimensional solid state NMR

AlPO-ERI, isostructural de l' $\mathrm{AlPO}_{4}$-17, a été préparé en utilisant la $N, N, N^{\prime}, N^{\prime}$-tetramethyl-1,6-hexanediamine comme molécule structurante et sa structure a été résolue sur monocristal. Le solide cristallise dans le groupe d'espace $P 2(1)\left(\mathrm{n}^{\circ}\right.$. 4) avec $a=13.163(14) \AA, b=14.793(15) \AA, c=13.215(14) \AA$ et $\beta=119.74(8)^{\circ}$. La symétrie n'est pas hexagonale, comme pour l'AlPO ${ }_{4}$ 17 préparé en présence de pipéridine, et la structure est localement ordonnée. Après calcination et réhydratation, le solide conserve une symétrie monoclinique et cristallise dans le groupe d'espace $P 2(1) / n\left(\mathrm{n}^{\circ}\right.$. 14) avec $a=13.283(17) \AA, b=14.910(14) \AA$, $c=22.76(3) \AA$ et $\beta=90.19(10)$. Les solides issus de synthèse, calcinés et réhydratés ont été étudiés par RMN du solide multidimensionnelle.

Mots clés : Aluminophosphate ; $\mathrm{AlPO}_{4}-17$; Érionite ; Synthèse ; Structure ; RMN du solide bidimensionnelle

\footnotetext{
* Corresponding author.

E-mail address: tuel@catalyse.cnrs.fr (A. Tuel).
} 


\section{Introduction}

$\mathrm{AlPO}_{4}-n$ are microporous crystalline aluminophosphates with open-framework structures similar to zeolites [1]. They are built up from strictly alternating corner-sharing aluminum and phosphorus tetrahedra. Their discovery was followed by the silicoaluminophosphates [2,3], titanium aluminophosphates [4], metal aluminophosphates [5-7] and metal silicoaluminophosphates [8], designated SAPO- $n$, TAPO- $n$, MeAPO- $n$ and MeAPSO- $n$, respectively. These compounds are still a matter of interest because of their properties as catalysts and molecular sieves. Many of them possess original framework topologies that do not exist in the family of microporous silicates or aluminosilicates. On the other hand, some AlPOs, SAPOs or MeAPOs are structurally related to zeolites. For example $\mathrm{AlPO}_{4}-17$ [9], $\mathrm{AlPO}_{4}-20$ [10], $\mathrm{AlPO}_{4}-34$ [11] and SAPO-37 [3] are known to possess structures with the erionite (ERI), sodalite (SOD), chabazite (CHA) and faujasite (FAU) framework topology, respectively. The crystal system can be the same for the zeolite and the aluminophosphate analog but space groups generally differ. Indeed, the space group symmetry for disordered $\mathrm{Si}$ and $\mathrm{Al}$ in zeolites has to be reduced to account for the strict ordering of $\mathrm{P}$ and $\mathrm{Al}$ in the aluminophosphate. Moreover, extraframework atoms like $\mathrm{O}$ or $\mathrm{F}$ can be present in as-made compounds, thus decreasing the symmetry of the framework. As an example, the triclinic form of $\mathrm{AlPO}_{4}-34$ (CHA framework topology) can only be obtained in the presence of fluorine. In the as-made compound, two fluorine atoms bridge two $\mathrm{Al}$ atoms of a four-ring, connecting two D6R's of the chabazitelike topology [12]. This leads to a distortion of the trigonal symmetry of chabazite, with space group $P \overline{1}$. Upon calcination, fluorine bridges are removed and the symmetry of the calcined material becomes rhombohedral, but the space group is $R \overline{3}$, which is still lower than the space group $R \overline{3} m$ of the zeolite.

Extraframework oxygen atoms, generally in the form of $\mathrm{OH}^{-}$groups, can also bridge aluminum atoms, leading to five-coordinate aluminum species. Such oxygen bridges have been found in several compounds, including $\mathrm{AlPO}_{4}-17$ [9] and $\mathrm{AlPO}_{4}-18$ [13]. In the particular case of $\mathrm{AlPO}_{4}-17$, oxygen species bridge aluminum atoms located in opposite six-rings, at the top and at the bottom of each cancrinite cage. These extraframework sites are partly occupied, all $\mathrm{Al}$ atoms in the sixrings being considered as forming, on average, one third of the time (or space) a tetrahedron and two thirds of the time (or space) a trigonal bipyramid. Each cancrinite cage thus contains two extraframework $\mathrm{OH}^{-}$groups, balancing the charge of the protonated template. In the case of a material prepared with piperidine, the unit cell formula is $\mathrm{Al}_{18} \mathrm{P}_{18} \mathrm{O}_{72} \cdot 4\left(\mathrm{C}_{5} \mathrm{NH}_{12}{ }^{+} \cdot \mathrm{OH}^{-}\right)$. Because of the disorder of extraframework hydroxyl species, no evidence was found for symmetry lower than hexagonal and the unit cell was described in space group $\mathrm{P}_{3} / \mathrm{m}$ ( $\mathrm{P}_{3} / \mathrm{mmc}$ for the corresponding zeolite) [9].

$\mathrm{AlPO}_{4}-17$ is generally synthesized under hydrothermal conditions in the presence of small cyclic amines like piperidine [9], quinuclidine [7,14] or cyclohexylamine $[12,15]$. However, Gao et al. [16] could also prepare $\mathrm{AlPO}_{4}-17$ from a non-aqueous medium using methylamine as template. Crystals are in the form of elongated hexagonal prisms, revealing the symmetry of the unit cell. Though their position has not been precisely determined, templating molecules are located in the large ellipsoidal cages of the structure. The distance between two organic molecules (piperidinium ions) in the prism corresponds approximately to half of the $c$-axis value, that is $\approx 7 \AA$ [9]. Theoretically, it would then be possible to replace two piperidinium ions by a single molecule, for example a doubly protonated diamine, with a N-N distance close to $7 \AA$. Patents effectively report the synthesis of SAPO-17 materials using hexamethonium ions [2], but the structure of the corresponding solids has never been studied.

The present work reports on the synthesis, structure determination and characterization of AlPO-ERI, isostructural to $\mathrm{AlPO}_{4}-17$, and obtained in the presence of $N, N, N^{\prime}, N^{\prime}$-tetramethyl-1,6-hexanediamine (TMHDA). Moreover, the structure of the calcined rehydrated compound is also reported. 


\section{Experimental section}

\subsection{Synthesis}

AlPO-ERI was synthesized under hydrothermal conditions in the presence of TMHDA as template. Aluminum isopropoxide $\mathrm{Al}\left(\mathrm{O}^{\mathrm{i}} \mathrm{Pr}\right)_{3}(98+\%$, Aldrich $)$ and phosphoric acid (85 wt.\% in water, Prolabo) were used as aluminum and phosphorus sources, respectively. Typically, $14.7 \mathrm{~g}$ of aluminum isopropoxide were dispersed in $30 \mathrm{ml}$ of water and the suspension was stirred for $2 \mathrm{~h}$. Then $4.92 \mathrm{ml}$ of $\mathrm{H}_{3} \mathrm{PO}_{4}$ were added dropwise and the obtained gel was stirred for an additional hour. Finally, $7.75 \mathrm{ml}$ of diamine were slowly added and stirring was maintained for an additional $2 \mathrm{~h}$. The resulting gel, with the composition $\mathrm{Al}_{2} \mathrm{O}_{3}-\mathrm{P}_{2} \mathrm{O}_{5}$-TMHDA$46 \mathrm{H}_{2} \mathrm{O}$ was transferred into a Teflon-lined stainless steel autoclave and heated at $200{ }^{\circ} \mathrm{C}$ for $60 \mathrm{~h}$. The solid, recovered by filtration, appeared in the form of elongated hexagonal prisms. It was washed with distilled water and air-dried at room temperature. Part of the crystals was calcined in air at $500{ }^{\circ} \mathrm{C}$ for $24 \mathrm{~h}$. After cooling down the temperature, the calcined AlPO-ERI was rehydrated under ambient atmosphere for 15 days.

\subsection{X-ray data collection and structure determination}

The crystals from the as made material are invariably twinned as manifested when viewed under the polarizing microscope. Therefore an attempt was made to cut a single crystal from such twins.

From both samples (as made and calcined/ rehydrated) a single crystal data set was collected at room temperature with a Picker 4-circle diffractometer with $\mathrm{Cu} \mathrm{K} \alpha$ radiation. The structure was solved using SHELX-86 [17] and refined with SHELX-93 [18]. Further details of the data collection and the crystallographic data are given in Table 1 . The crystal from the as made material still showed some twinning and it was necessary to apply a twin refinement with restrained anisotropic displacement parameters. In addition, restraints on bond distances and bond angles had to be applied to the template molecule in the as made material. Selected interatomic distances and bond angles are reported in Table 2.

\subsection{Characterization}

Thermal analysis data were recorded on a Setaram TGDT A92 apparatus. Samples were heated in air from 25 to $750{ }^{\circ} \mathrm{C}$ at a heating rate of $5{ }^{\circ} \mathrm{C} / \mathrm{min}$.

Table 1

Crystal data and structure refinement for AlPO-ERI

\begin{tabular}{|c|c|c|}
\hline Compound name & AlPO-ERI as made & AlPO-ERI, rehydrated \\
\hline Empirical formula & $\mid \mathrm{C}_{10} \mathrm{H}_{26} \mathrm{~N}_{2}, 2 \mathrm{OHI}\left[\mathrm{Al}_{9} \mathrm{P}_{9} \mathrm{O}_{36}\right]$ & $\mid 17 \mathrm{H}_{2} \mathrm{Ol}\left[\mathrm{Al}_{9} \mathrm{P}_{9} \mathrm{O}_{36}\right]$ \\
\hline Formula weight & 1305.89 & 1403.82 \\
\hline Space group & $P 2(1)($ No. 4$)$ & $P 2(1) / n$ (No. 14) \\
\hline$Z$ & 2 & 4 \\
\hline$a(\AA)$ & $13.163(14)$ & $13.283(17)$ \\
\hline$b(\AA)$ & $14.793(15)$ & $14.910(14)$ \\
\hline$c(\AA)$ & $13.215(14)$ & $22.76(3)$ \\
\hline$\beta\left(^{\circ}\right)$ & $119.74(8)$ & $90.19(10)$ \\
\hline$\lambda(\AA)$ & 1.54178 & 1.54178 \\
\hline Crystal size (mm) & $0.1 \times 0.1 \times 0.1$ & $0.1 \times 0.1 \times 0.1$ \\
\hline$\theta$ range $\left(^{\circ}\right)$ & $3.85-50.00$ & $3.54-49.97$ \\
\hline Index ranges & $-13 \leq h \leq 11,0 \leq k \leq 14,0 \leq l \leq 13$ & $-13 \leq h \leq 13,-14 \leq k \leq 0,-22 \leq l \leq 0$ \\
\hline Number of reflections $(>2 \sigma(I))$ & 1687 & 2981 \\
\hline Number of reflections & 2403 & 4616 \\
\hline Number of structural parameters & 624 & 668 \\
\hline Number of restraints & 509 & 18 \\
\hline$R\left(F^{2}\right)$ for all/> $\left.2 \sigma(I)\right)$ reflections & $0.0845 / 0.0628$ & $0.1268 / 0.0767$ \\
\hline$R \mathrm{w}\left(F^{2}\right)$ for all//>2 $\left.\sigma(I)\right)$ reflections & $0.1915 / 0.1627$ & $0.2245 / 0.1986$ \\
\hline Refinement method & Full-matrix LS on $F^{2}$ & Full-matrix LS on $F^{2}$ \\
\hline
\end{tabular}


Table 2

Interatomic distances $(\AA)$ and bond angles $\left(^{\circ}\right)$ of as made AlPO-ERI

\begin{tabular}{|c|c|}
\hline $\mathrm{P}(1)-\mathrm{O}(1)$ & $1.50(2)$ \\
\hline $\mathrm{P}(1)-\mathrm{O}(3)$ & $1.51(2)$ \\
\hline $\mathrm{P}(1)-\mathrm{O}(2)$ & $1.513(12)$ \\
\hline $\mathrm{P}(1)-\mathrm{O}(4)$ & $1.524(13)$ \\
\hline $\mathrm{P}(2)-\mathrm{O}(5)$ & $1.501(12)$ \\
\hline $\mathrm{P}(2)-\mathrm{O}(8)$ & $1.507(13)$ \\
\hline $\mathrm{P}(2)-\mathrm{O}(7)$ & $1.51(2)$ \\
\hline $\mathrm{P}(2)-\mathrm{O}(6)$ & $1.53(2)$ \\
\hline $\mathrm{P}(3)-\mathrm{O}(11)$ & $1.43(2)$ \\
\hline $\mathrm{P}(3)-\mathrm{O}(12)$ & $1.504(11)$ \\
\hline $\mathrm{P}(3)-\mathrm{O}(10)$ & $1.549(14)$ \\
\hline $\mathrm{P}(3)-\mathrm{O}(9)$ & $1.553(17)$ \\
\hline $\mathrm{P}(4)-\mathrm{O}(16)$ & $1.43(2)$ \\
\hline $\mathrm{P}(4)-\mathrm{O}(15)$ & $1.469(16)$ \\
\hline $\mathrm{P}(4)-\mathrm{O}(13)$ & $1.52(2)$ \\
\hline $\mathrm{P}(4)-\mathrm{O}(14)$ & $1.568(19)$ \\
\hline $\mathrm{P}(5)-\mathrm{O}(20)$ & $1.41(3)$ \\
\hline $\mathrm{P}(5)-\mathrm{O}(17)$ & $1.484(18)$ \\
\hline $\mathrm{P}(5)-\mathrm{O}(19)$ & $1.49(2)$ \\
\hline $\mathrm{P}(5)-\mathrm{O}(18)$ & $1.58(2)$ \\
\hline $\mathrm{P}(6)-\mathrm{O}(22)$ & $1.47(2)$ \\
\hline $\mathrm{P}(6)-\mathrm{O}(21)$ & $1.48(2)$ \\
\hline $\mathrm{P}(6)-\mathrm{O}(23)$ & $1.50(2)$ \\
\hline $\mathrm{P}(6)-\mathrm{O}(24)$ & $1.531(17)$ \\
\hline $\mathrm{P}(7)-\mathrm{O}(25)$ & $1.452(19)$ \\
\hline $\mathrm{P}(7)-\mathrm{O}(26)$ & $1.52(2)$ \\
\hline $\mathrm{P}(7)-\mathrm{O}(28)$ & $1.54(2)$ \\
\hline $\mathrm{P}(7)-\mathrm{O}(27)$ & $1.57(2)$ \\
\hline $\mathrm{P}(8)-\mathrm{O}(29)$ & $1.44(2)$ \\
\hline $\mathrm{P}(8)-\mathrm{O}(32)$ & $1.53(3)$ \\
\hline $\mathrm{P}(8)-\mathrm{O}(30)$ & $1.54(2)$ \\
\hline $\mathrm{P}(8)-\mathrm{O}(31)$ & $1.56(3)$ \\
\hline $\mathrm{P}(9)-\mathrm{O}(35)$ & $1.47(2)$ \\
\hline $\mathrm{P}(9)-\mathrm{O}(34)$ & $1.51(2)$ \\
\hline $\mathrm{P}(9)-\mathrm{O}(33)$ & $1.54(2)$ \\
\hline $\mathrm{P}(9)-\mathrm{O}(36)$ & $1.57(2)$ \\
\hline $\mathrm{Al}(1)-\mathrm{O}(31)$ & $1.67(3)$ \\
\hline $\mathrm{Al}(1)-\mathrm{O}(5)$ & $1.715(12)$ \\
\hline $\mathrm{Al}(1)-\mathrm{O}(21)$ & $1.77(2)$ \\
\hline $\mathrm{Al}(1)-\mathrm{O}(2)$ & $1.774(13)$ \\
\hline $\mathrm{Al}(2)-\mathrm{O}(14)$ & $1.67(2)$ \\
\hline $\mathrm{Al}(2)-\mathrm{O}(12)$ & $1.708(11)$ \\
\hline $\mathrm{Al}(2)-\mathrm{O}(8)$ & $1.732(14)$ \\
\hline $\mathrm{Al}(2)-\mathrm{O}(25)$ & $1.76(2)$ \\
\hline $\mathrm{Al}(3)-\mathrm{O}(4)$ & $1.687(14)$ \\
\hline $\mathrm{Al}(3)-\mathrm{O}(10)$ & $1.708(13)$ \\
\hline $\mathrm{Al}(3)-\mathrm{O}(18)$ & $1.72(2)$ \\
\hline $\mathrm{Al}(3)-\mathrm{O}(34)$ & $1.73(2)$ \\
\hline $\mathrm{Al}(4)-\mathrm{O}(3)$ & $1.71(2)$ \\
\hline $\mathrm{Al}(4)-\mathrm{O}(36)$ & $1.73(2)$ \\
\hline $\mathrm{Al}(4)-\mathrm{O}(24)$ & $1.74(2)$ \\
\hline $\mathrm{Al}(4)-\mathrm{O}(16)$ & $1.76(2)$ \\
\hline $\mathrm{Al}(4)-\mathrm{O}(2 \mathrm{H})$ & $2.24(6)$ \\
\hline $\mathrm{Al}(5)-\mathrm{O}(17)$ & $1.714(19)$ \\
\hline $\mathrm{Al}(5)-\mathrm{O}(32)$ & $1.72(3)$ \\
\hline $\mathrm{Al}(5)-\mathrm{O}(13)$ & $1.76(3)$ \\
\hline $\mathrm{Al}(5)-\mathrm{O}(7)$ & $1.77(2)$ \\
\hline $\mathrm{Al}(5)-\mathrm{O}(3 \mathrm{H})$ & $2.13(5)$ \\
\hline
\end{tabular}

\begin{tabular}{|c|c|}
\hline $\mathrm{P}(1)-\mathrm{O}(1)$ & $1.50(2)$ \\
\hline $\mathrm{Al}(6)-\mathrm{O}(22)$ & $1.81(3)$ \\
\hline $\mathrm{Al}(6)-\mathrm{O}(19)$ & $1.82(2)$ \\
\hline $\mathrm{Al}(6)-\mathrm{O}(11)$ & $1.84(2)$ \\
\hline $\mathrm{Al}(6)-\mathrm{O}(28)$ & $1.86(2)$ \\
\hline $\mathrm{Al}(6)-\mathrm{O}(1 \mathrm{H})$ & $1.96(3)$ \\
\hline $\mathrm{Al}(7)-\mathrm{O}(27)$ & $1.68(2)$ \\
\hline $\mathrm{Al}(7)-\mathrm{O}(29)$ & $1.73(2)$ \\
\hline $\mathrm{Al}(7)-\mathrm{O}(1)$ & $1.76(2)$ \\
\hline $\mathrm{Al}(7)-\mathrm{O}(20)$ & $1.94(3)$ \\
\hline $\mathrm{Al}(7)-\mathrm{O}(2 \mathrm{H})$ & $2.00(5)$ \\
\hline $\mathrm{Al}(8)-\mathrm{O}(30)$ & $1.72(3)$ \\
\hline $\mathrm{Al}(8)-\mathrm{O}(35)$ & $1.77(2)$ \\
\hline $\mathrm{Al}(8)-\mathrm{O}(9)$ & $1.777(16)$ \\
\hline $\mathrm{Al}(8)-\mathrm{O}(15)$ & $1.895(16)$ \\
\hline $\mathrm{Al}(8)-\mathrm{O}(1 \mathrm{H})$ & $1.91(2)$ \\
\hline $\mathrm{Al}(9)-\mathrm{O}(33)$ & $1.70(2)$ \\
\hline $\mathrm{Al}(9)-\mathrm{O}(6)$ & $1.72(2)$ \\
\hline $\mathrm{Al}(9)-\mathrm{O}(26)$ & $1.74(3)$ \\
\hline $\mathrm{Al}(9)-\mathrm{O}(23)$ & $1.81(2)$ \\
\hline $\mathrm{Al}(9)-\mathrm{O}(3 \mathrm{H})$ & $2.22(5)$ \\
\hline $\mathrm{P}(1)-\mathrm{O}(1)-\mathrm{Al}(7)$ & $139.3(13)$ \\
\hline $\mathrm{P}(1)-\mathrm{O}(2)-\mathrm{Al}(1)$ & $142.9(10)$ \\
\hline $\mathrm{P}(1)-\mathrm{O}(3)-\mathrm{Al}(4)$ & $141.0(14)$ \\
\hline $\mathrm{P}(1)-\mathrm{O}(4)-\mathrm{Al}(3)$ & $170.3(10)$ \\
\hline $\mathrm{P}(2)-\mathrm{O}(5)-\mathrm{Al}(1)$ & $170.3(11)$ \\
\hline $\mathrm{P}(2)-\mathrm{O}(6)-\mathrm{Al}(9)$ & $138.7(15)$ \\
\hline $\mathrm{P}(2)-\mathrm{O}(7)-\mathrm{Al}(5)$ & $137.7(15)$ \\
\hline $\mathrm{P}(2)-\mathrm{O}(8)-\mathrm{Al}(2)$ & $148.0(8)$ \\
\hline $\mathrm{P}(3)-\mathrm{O}(9)-\mathrm{Al}(8)$ & $131.2(10)$ \\
\hline $\mathrm{P}(3)-\mathrm{O}(10)-\mathrm{Al}(3)$ & $146.8(9)$ \\
\hline $\mathrm{P}(3)-\mathrm{O}(11)-\mathrm{Al}(6)$ & $133.5(13)$ \\
\hline $\mathrm{P}(3)-\mathrm{O}(12)-\mathrm{Al}(2)$ & $171.9(11)$ \\
\hline $\mathrm{P}(4)-\mathrm{O}(13)-\mathrm{Al}(5)$ & $143.0(13)$ \\
\hline $\mathrm{P}(4)-\mathrm{O}(14)-\mathrm{Al}(2)$ & $152.0(14)$ \\
\hline $\mathrm{P}(4)-\mathrm{O}(15)-\mathrm{Al}(8)$ & $140.1(10)$ \\
\hline $\mathrm{P}(4)-\mathrm{O}(16)-\mathrm{Al}(4)$ & $157.6(14)$ \\
\hline $\mathrm{P}(5)-\mathrm{O}(17)-\mathrm{Al}(5)$ & $146.1(15)$ \\
\hline $\mathrm{P}(5)-\mathrm{O}(18)-\mathrm{Al}(3)$ & $146.0(18)$ \\
\hline $\mathrm{P}(5)-\mathrm{O}(19)-\mathrm{Al}(6)$ & $141.8(13)$ \\
\hline $\mathrm{P}(5)-\mathrm{O}(20)-\mathrm{Al}(7)$ & $134.4(19)$ \\
\hline $\mathrm{P}(6)-\mathrm{O}(21)-\mathrm{Al}(1)$ & $147.5(12)$ \\
\hline $\mathrm{P}(6)-\mathrm{O}(22)-\mathrm{Al}(6)$ & $143.4(14)$ \\
\hline $\mathrm{P}(6)-\mathrm{O}(23)-\mathrm{Al}(9)$ & $144.2(16)$ \\
\hline $\mathrm{P}(6)-\mathrm{O}(24)-\mathrm{Al}(4)$ & $138.1(15)$ \\
\hline $\mathrm{P}(7)-\mathrm{O}(25)-\mathrm{Al}(2)$ & $150.6(14)$ \\
\hline $\mathrm{P}(7)-\mathrm{O}(26)-\mathrm{Al}(9)$ & $147.9(14)$ \\
\hline $\mathrm{P}(7)-\mathrm{O}(27)-\mathrm{Al}(7)$ & $148.2(13)$ \\
\hline $\mathrm{P}(7)-\mathrm{O}(28)-\mathrm{Al}(6)$ & $140.3(12)$ \\
\hline $\mathrm{P}(8)-\mathrm{O}(29)-\mathrm{Al}(7)$ & $151(2)$ \\
\hline $\mathrm{P}(8)-\mathrm{O}(30)-\mathrm{Al}(8)$ & $151.0(14)$ \\
\hline $\mathrm{P}(8)-\mathrm{O}(31)-\mathrm{Al}(1)$ & $147.1(17)$ \\
\hline $\mathrm{P}(8)-\mathrm{O}(32)-\mathrm{Al}(5)$ & $141(2)$ \\
\hline $\mathrm{P}(9)-\mathrm{O}(33)-\mathrm{Al}(9)$ & $141.9(14)$ \\
\hline $\mathrm{P}(9)-\mathrm{O}(34)-\mathrm{Al}(3)$ & $152.1(17)$ \\
\hline $\mathrm{P}(9)-\mathrm{O}(35)-\mathrm{Al}(8)$ & $148.9(14)$ \\
\hline $\mathrm{P}(9)-\mathrm{O}(36)-\mathrm{Al}(4)$ & $135.7(15)$ \\
\hline $\mathrm{Al}(8)-\mathrm{O}(1 \mathrm{H})-\mathrm{Al}(6)$ & $142.5(6)$ \\
\hline $\mathrm{Al}(7)-\mathrm{O}(2 \mathrm{H})-\mathrm{Al}(4)$ & $143.9(15)$ \\
\hline $\mathrm{Al}(5)-\mathrm{O}(3 \mathrm{H})-\mathrm{Al}(9)$ & $134.8(13)$ \\
\hline
\end{tabular}


SEM pictures were obtained on a Hitachi S800 microscope.

Solid-state magic angle spinning (MAS) NMR spectra were acquired on a Bruker DSX 400 spectrometer operating at 104.2 and $161.2 \mathrm{MHz}$ for ${ }^{27} \mathrm{Al}$ and ${ }^{31} \mathrm{P}$ nuclei, respectively. Samples were spun at $11 \mathrm{kHz}$ at the magic angle in a double-bearing $4 \mathrm{~mm}$ probe head. The pulse lengths were $2 \mu \mathrm{s}(\pi / 4)$ and $0.7 \mu \mathrm{s}(\pi / 6)$, and the recycle delays were 30 and $1 \mathrm{~s}$ for ${ }^{31} \mathrm{P}$ and ${ }^{27} \mathrm{Al}$ nuclei, respectively. ${ }^{31} \mathrm{P}$ and ${ }^{27} \mathrm{Al}$ chemical shifts were referenced to $\mathrm{H}_{3} \mathrm{PO}_{4}(85$ wt. \% $)$ and $\mathrm{Al}\left(\mathrm{H}_{2} \mathrm{O}\right)_{6}{ }^{3+}$, respectively.

Two dimensional-five quanta (2D-5Q) ${ }^{27} \mathrm{Al}$ MAS NMR spectra were collected at $14 \mathrm{kHz}$ using the twopulse sequence originally reported by Medek et al. [19] and further modified by Fernandez and Amoureux [20] for the study of $S=5 / 2$ nuclei. The five quanta coherence was excited with a $2 \mu$ s pulse, corresponding to a radio frequency of $175 \mathrm{kHz}$. Three hundred twenty scans were accumulated for each free induction decay with a recycle delay of $500 \mathrm{~ms}$. One hundred twentyeight time domain real data points were acquired in the indirect dimension, and pure phase spectra were obtained using the TPPI scheme [21,22]. A shearing transformation was applied to the spectra in order to obtain isotropic projections parallel to the $\mathrm{f}_{1}$ direction.

${ }^{27} \mathrm{Al}-{ }^{31} \mathrm{P} \mathrm{CP} / \mathrm{MAS}$ experiments were carried out using a three-channel ${ }^{1} \mathrm{H}-\mathrm{X}-\mathrm{Y}$ probe head and a conventional spin lock sequence with a spin-locking field of 4 and $5 \mathrm{kHz}$ for ${ }^{27} \mathrm{Al}$ and ${ }^{31} \mathrm{P}$, respectively. $2 \mathrm{D}{ }^{27} \mathrm{Al}-$ ${ }^{31} \mathrm{P}$ CP/MAS NMR spectra were obtained by encoding the aluminum evolution frequencies in an initial time period after the $90^{\circ}$ pulse. Pure absorption phase NMR line shapes in both dimensions were obtained by cycling the phase of the $90^{\circ}$ pulse using the TPPI scheme $[21,22]$. A more homogeneous polarization transfer was achieved by linear amplitude modulation of the spinlock field on aluminum (the amplitude was decreased by $10 \%$ from 4 to $3.6 \mathrm{kHz}$ ). The contact time was $1.5 \mathrm{~ms}$ and the recycle delay was $300 \mathrm{~ms}$. In a typical experiment, 2048 scans were accumulated for each of the 64 time-domain data points acquired in the aluminum dimension.

\section{Results and discussion}

The X-ray powder diffraction pattern of the solid matches exactly that of $\mathrm{AlPO}_{4}-17$ prepared with pip- eridine as template (JCPDS 85-1197). The absence of extra-peaks and the high intensity of the reflections indicate that the phase is pure and highly crystalline. The organic molecule is incorporated intact in the channels, as evidenced by ${ }^{13} \mathrm{C}$ NMR. Differences in chemical shift between the molecule in the channels of the aluminophosphate and in the solution are an indication that the latter is doubly protonated. As mentioned in Section 1, the distance between $\mathrm{N}$ atoms in the organic molecule is of prime importance for the crystallization of $\mathrm{AlPO}_{4}-17$. Heating gels with the same molar composition but containing shorter diamines like $N, N, N^{\prime}, N^{\prime}$ tetramethylethylenediamine or $N, N, N^{\prime}, N^{\prime}$-tetramethyl1,3-diaminoprpane led to the crystallization of $\mathrm{AlPO}_{4}$ 21. These two templates are fragmented during synthesis and the obtained fragments are incorporated into the aluminophosphate framework. The presence of methyl groups on the nitrogen atoms is also crucial. Using 1,6-hexanediamine as template yielded layered materials for crystallization temperatures between 120 and $200{ }^{\circ} \mathrm{C}$.

The ${ }^{27} \mathrm{Al}$ NMR spectrum of the aluminophosphate is composed of two signals at ca. 15 and 40 ppm (Fig. 1). These signals have been previously assigned to the eight five-coordinate and the 10 four-coordinate $\mathrm{Al}$ atoms of the unit cell, respectively [23]. On the basis of X-ray powder diffraction and ${ }^{27} \mathrm{Al} \mathrm{NMR}$, the solid prepared with the diamine is thus strictly similar to the previously reported $\mathrm{AlPO}_{4}-17$. However, the ${ }^{31} \mathrm{P}$ NMR spectrum is complex and shows several lines with chemical shifts between -15 and $-35 \mathrm{ppm}$, characteristic of $\mathrm{PO}_{4}$ tetrahedra (Fig. 1). After deconvolution, the spectrum consists of seven lines with relative intensities $1: 1: 1: 3: 1: 1: 1$, suggesting the presence of at least nine crystallographically non-equivalent $P$ sites in the structure (Table 3 ). The presence of several ${ }^{31} \mathrm{P}$ NMR lines is in contradiction with previous data recorded on a solid prepared with piperidine $[9,23]$, which indicates that the crystal symmetry of the title material is probably locally reduced. The local reduction of the symmetry was confirmed by ${ }^{27} \mathrm{Al}$ 2D-5Q MAS NMR (Fig. 2). This technique provides enhanced resolution in the indirect dimension as compared with ordinary MAS spectra since the second order quadrupolar broadening is removed and the chemical shift dispersion is amplified, as it would be in a field approximately five times more intense. Nine signals can be separated in the indirect dimension $\mathrm{f}_{1}: 5$ (signals $1-5$ ) correspond to $\mathrm{AlO}_{4}$ 

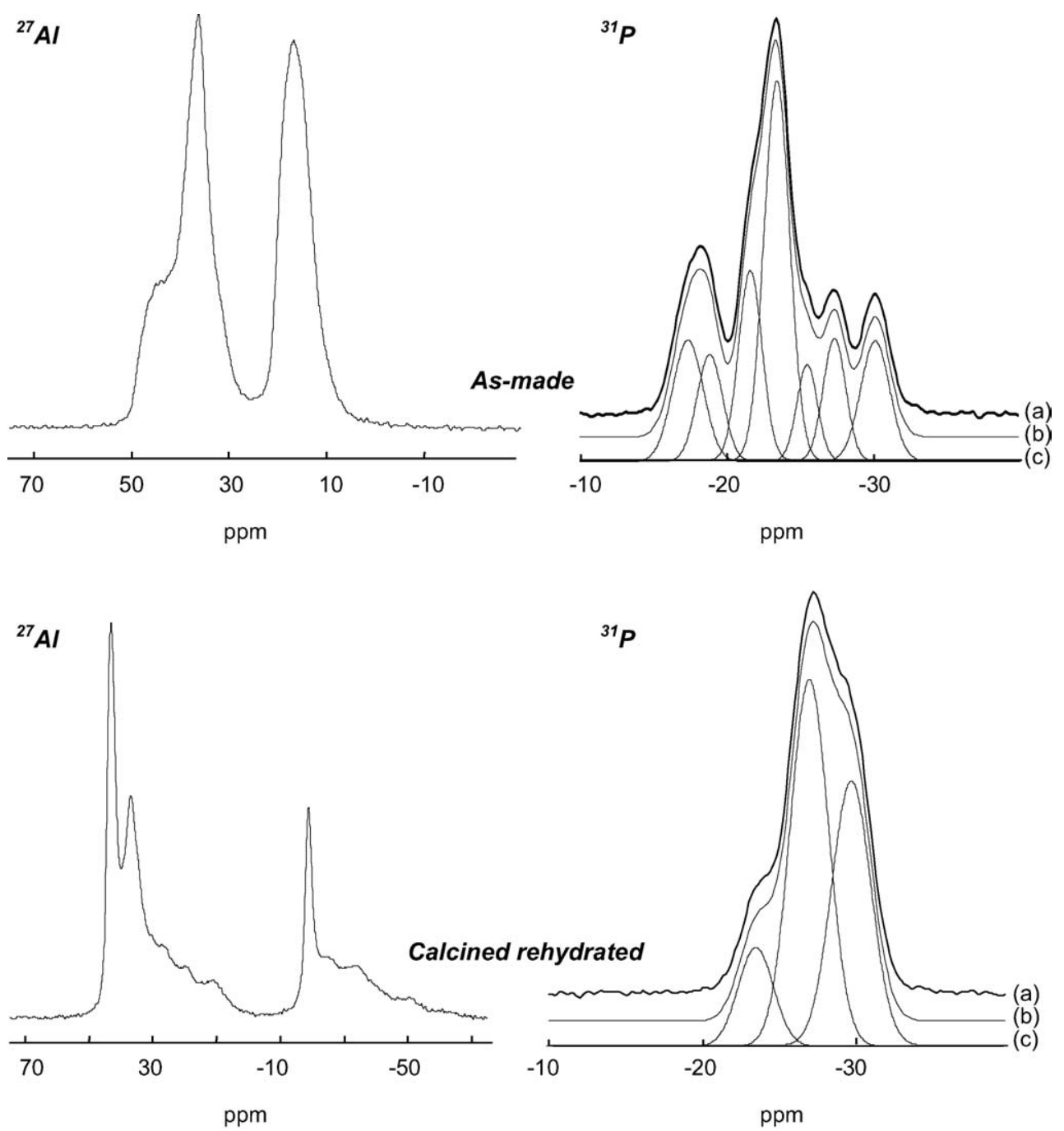

Fig. $1 .{ }^{27} \mathrm{Al}$ and ${ }^{31} \mathrm{P}$ NMR spectra of as made and calcined rehydrated AlPO-ERI. (a): experimental spectra, (b): simulated spectra and (c): decomposition of the simulated spectrum with Gaussian lines.

tetrahedra and 4 (signals 6-9) to pentacoordinated $\mathrm{AlO}_{5}$ species. The $\mathrm{AlO}_{4}: \mathrm{AlO}_{5}$ ratio between tetra and pentacoordinated $\mathrm{Al}$ species is 5:4, in agreement with the previous structure determination [9].

The organic molecule is located inside the large ellipsoidal cages of the ERI structure (Fig. 3). Each ammonium group occupies approximately the same position as piperidine molecules in the structure reported by Pluth et al. [9], with a N-N distance of $6.82 \AA$. For piperidinium ions, $\mathrm{C}$ and $\mathrm{N}$ atoms in the rings could not be easily distinguished and the structure was refined in the hexagonal space group $\mathrm{P}_{3} / \mathrm{m}$. By contrast, diamine molecules are ordered in the structure; all atom
Table 3

Chemical shifts (ppm) and relative intensity (\%) of Gaussian components obtained after deconvolution of ${ }^{31} \mathrm{P}$ NMR spectra of as-made and calcined rehydrated AlPO-ERI

\begin{tabular}{lllll}
\hline & As made & & \multicolumn{2}{c}{ Calcined rehydrated } \\
\cline { 1 - 2 }$\delta(\mathrm{ppm})$ & $I_{\text {rel. }}(\%)$ & & $\delta(\mathrm{ppm})$ & $I_{\text {rel. }}(\%)$ \\
\hline-17.34 & 10.98 & -23.79 & 11 \\
-18.85 & 11.35 & -27.02 & 45 \\
-21.65 & 12.29 & -29.91 & 44 \\
-23.46 & 32.54 & & \\
-25.52 & 10.21 & & \\
-27.38 & 11.36 & & \\
-30.8 & 11.27 & & \\
\hline
\end{tabular}




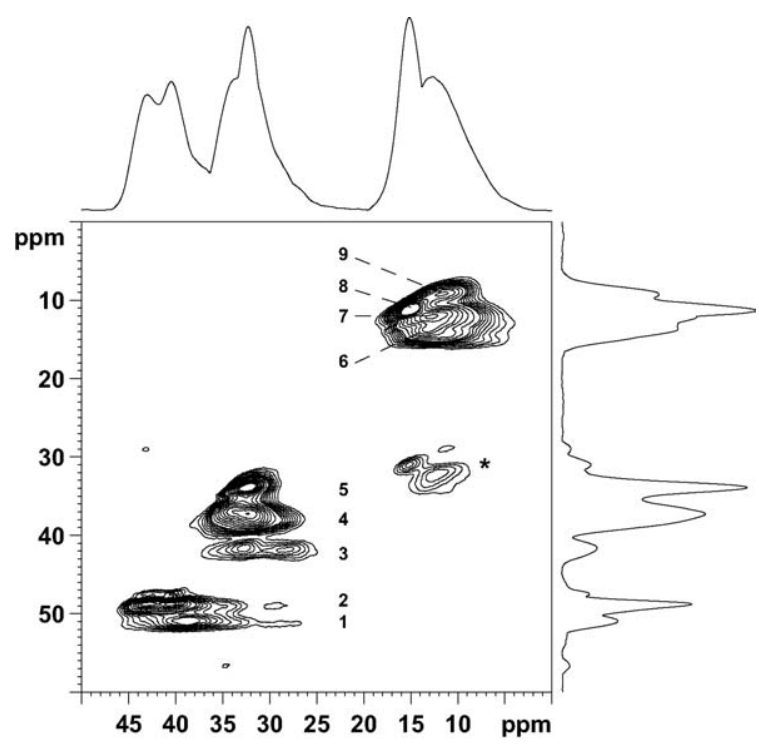

Fig. 2. Sheared ${ }^{27} \mathrm{Al} 2 \mathrm{D}-5 \mathrm{Q}$ MAS NMR spectrum of as-made AlPOERI. Asterisks denote spinning side bands.

positions could be located and are fully occupied. The use of TMDAH molecules to synthesize $\mathrm{AlPO}_{4}$ 17 materials results in a decrease of the symmetry of the aluminophosphate from hexagonal to monoclinic, as clearly evidenced by solid-state NMR. Therefore, this symmetry reduction seems to be induced by the templating molecule, but the exact mechanism is not clear except for the fact that the template is ordered in

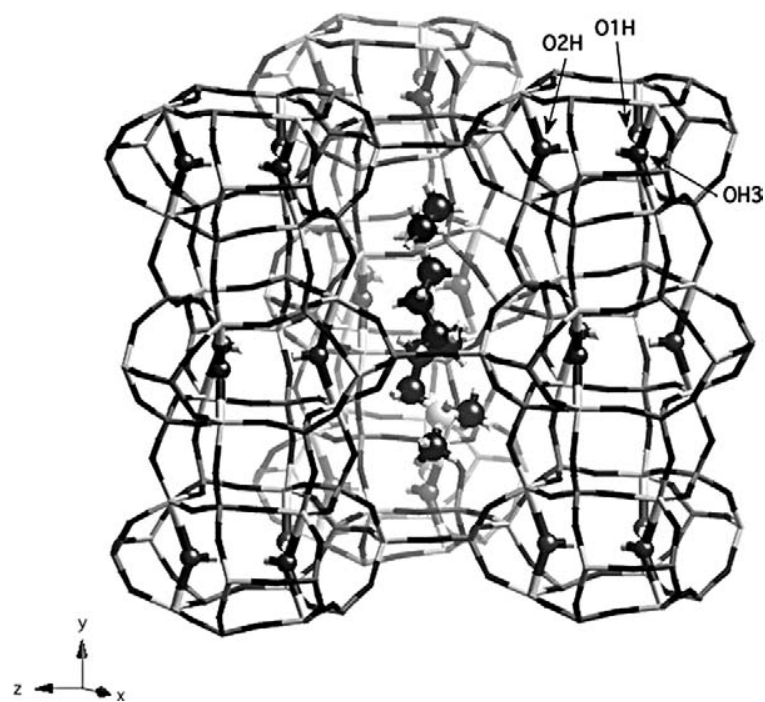

Fig. 3. Structure of as-made AlPO-ERI showing the template in the large cage and $\mathrm{OH}$ groups in the $\mathrm{CAN}$ cage. $\mathrm{O} 1 \mathrm{H}, \mathrm{O} 2 \mathrm{H}$ and $\mathrm{O} 3 \mathrm{H}$ are labeled. Dark gray: P tetrahedra, light gray: Al polyhedra. this space group. The lower symmetry leads to the existence of nine crystallographically non-equivalent $\mathrm{P}$ and $\mathrm{Al}$ sites in the unit cell, in agreement with ${ }^{27} \mathrm{Al}$ and ${ }^{31} \mathrm{P}$ NMR data. The positive charges of the organic molecule are balanced by extraframework $\mathrm{OH}$ groups, bridging $\mathrm{Al}$ atoms at the top and at the bottom of each cancrinite cage. Each diamine molecule is doubly protonated; so it has to be associated with two hydroxyl groups to maintain the neutrality of the framework. As a consequence, four of the six aluminum atoms located in the six-rings at the top and at the bottom of the cancrinite cage become pentacoordinated, the two others remaining tetrahedrally coordinated. From X-ray diffraction data, only one $\mathrm{OH}$ group $(\mathrm{O} 1 \mathrm{H})$ in the structure is a fully occupied position. The second one was considered to be statistically distributed over the two other positions in the cancrinite cage. In the case of a solid prepared with piperidine, $\mathrm{OH}$ groups can not be ordered (because of the hexagonal symmetry) and all the six $\mathrm{Al}$ atoms have to be considered as forming on average two thirds of the time a trigonal bipyramid and one third of the time a tetrahedron. The fact that one position is fully occupied in the solid containing the diamine may result from a specific interaction between the template and the framework. However, the ammonium head groups of the organic molecule cannot get in close contact with any of the extraframework $\mathrm{OH}$ groups because these groups are located in the cancrinite cage and are therefore not in the same cage as the template.

The presence of nine distinct signals in the ${ }^{27} \mathrm{Al}$ 2D-5Q MAS NMR spectrum (Fig. 2) is a strong indication that the two $\mathrm{OH}$ groups are locally ordered. A possible arrangement for the extraframework hydroxyl groups in a cancrinite cage is represented in Fig. $4(\mathrm{O} 1 \mathrm{H}$ and $\mathrm{O} 2 \mathrm{H}$ are fully occupied, $\mathrm{O} 3 \mathrm{H}$ is vacant. An equally valid arrangement would be to have $\mathrm{O} 2 \mathrm{H}$ vacant and $\mathrm{O} 3 \mathrm{H}$ fully occupied, and the following arguments could be made equally well with this assumption. Following this arrangement, $\mathrm{Al}(4), \mathrm{Al}(6), \mathrm{Al}(7)$ and $\mathrm{Al}(8)$ are pentacoordinated whilst $\mathrm{Al}(1), \mathrm{Al}(2), \mathrm{Al}(3), \mathrm{Al}(5)$ and $\mathrm{Al}(9)$ possess a tetrahedral coordination. $\mathrm{Al}(5)$ and $\mathrm{Al}(9)$, located in the upper and lower six-rings of the cancrinite cage, respectively, are structurally different from $\mathrm{Al}(1), \mathrm{Al}(2)$ and $\mathrm{Al}(3)$. Thus, in the tetrahedral region of the NMR spectrum (32-45 ppm) the two signals (signals 1 and 2) can be reasonably assigned to $\mathrm{Al}(5)$ and $\mathrm{Al}(9)$ and the group of three signals (signals 3-5) to 


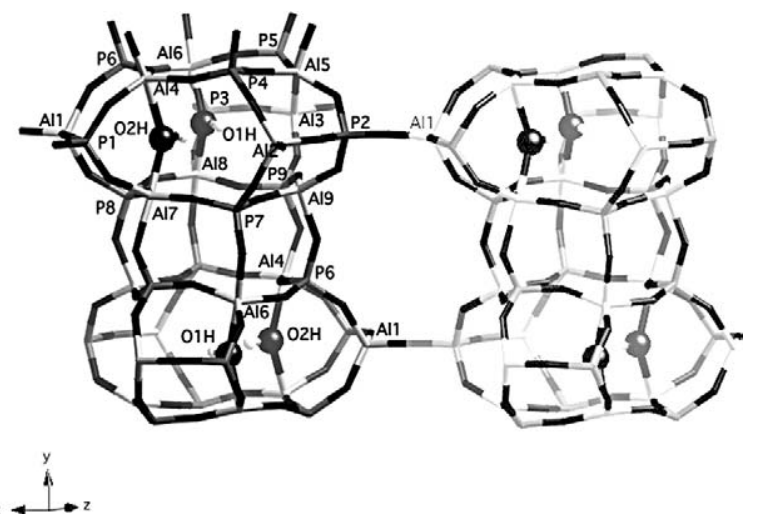

Fig. 4. View of 2 cancrinite cages in the same column and a possible arrangement of $\mathrm{OH}$ groups $(\mathrm{O} 1 \mathrm{H}$ and $\mathrm{O} 2 \mathrm{H}$ fully occupied; $\mathrm{O} 3 \mathrm{H}$ vacant). $\mathrm{Al}, \mathrm{P}$ and extraframework $\mathrm{OH}$ groups are labeled. Dark gray: $\mathrm{P}$ tetrahedra, light gray: Al polyhedra.

$\mathrm{Al}(1), \mathrm{Al}(2)$ and $\mathrm{Al}(3)$. Finally, the four signals around $15 \mathrm{ppm}$ represent the five-coordinate $\mathrm{Al}(4), \mathrm{Al}(6), \mathrm{Al}(7)$ and $\mathrm{Al}(8)$ species. This assignment is supported by the following argument. The atoms $\mathrm{Al}(5)$ and $\mathrm{Al}(9)$ are tetrahedrally coordinated with $\mathrm{Al}-\mathrm{O}-\mathrm{P}$ bond angle values between 137.7 and $147.9^{\circ}$ (Table 2), which indicates more or less undistorted environment (resonances at ca. $45 \mathrm{ppm}$ ). On the other hand, $\mathrm{Al}(1), \mathrm{Al}(2)$ and $\mathrm{Al}(3)$ share 3 oxygens with $\mathrm{P}$ atoms in the same cancrinite cage, with $\mathrm{Al}-\mathrm{O}-\mathrm{P}$ bond angle values in the range of 146.0-152.1 ${ }^{\circ}$, but the fourth oxygen connects aluminum atoms with $\mathrm{P}$ atoms located in a neighboring column, with a Al-O-P bond angle value higher than $170^{\circ}$ (Table 2). This high value modifies the geometry and the distribution of charges around $\mathrm{Al}$ atoms, which probably influences their NMR chemical shift and line shape and reduces it to ca. 35 ppm (signals 3-5 in Fig. 2).

More information about the local ordering of the framework was obtained from the $2 \mathrm{D}{ }^{27} \mathrm{Al}-{ }^{31} \mathrm{P}$ CP/MAS NMR spectrum (Fig. 5). This technique, based on a polarization transfer between neighboring $\mathrm{P}$ and $\mathrm{Al}$ atoms, give a direct picture of framework connectivities. In the $f_{1}$ dimension, representing the aluminum spectrum, the resolution is not as good as that of the 2D-5Q spectrum. However, the two types of tetrahedrally coordinated $\mathrm{Al}$ species, resonating at 43 and $35 \mathrm{ppm}$, are well separated. The correlation spectrum shows that the $2 \mathrm{P}$ atoms with a chemical shift around $-18 \mathrm{ppm}$ are not bonded to aluminum atoms resonating at $43 \mathrm{ppm}$. Also, the $\mathrm{P}$ atom corresponding to the ${ }^{31} \mathrm{P}$ NMR signal at $-32 \mathrm{ppm}$ is not connected to pentacoordinated $\mathrm{Al}$ species. From the representation of the

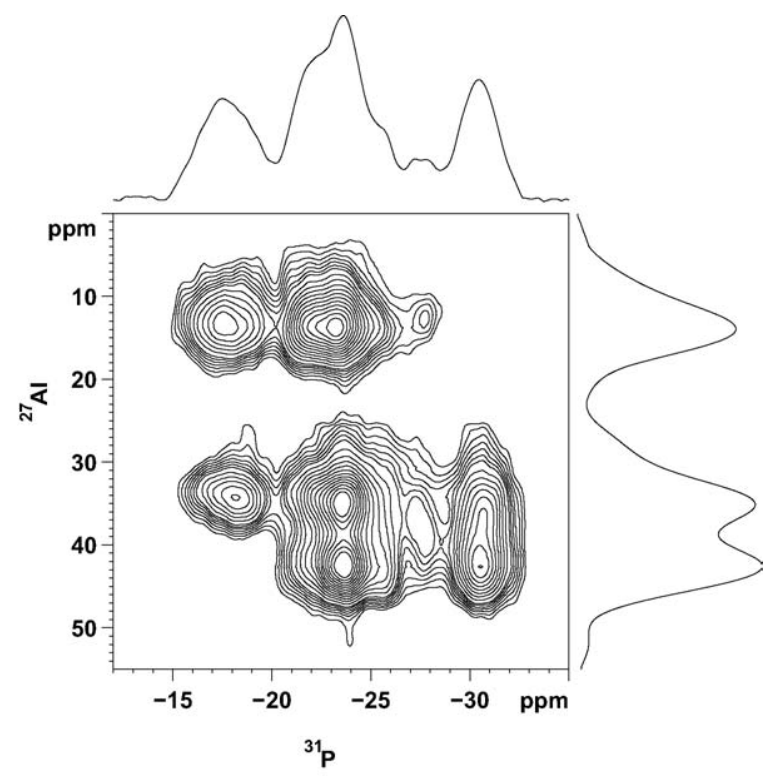

Fig. 5. Two-dimensional ${ }^{27} \mathrm{Al}-{ }^{31} \mathrm{P} \mathrm{CP} / \mathrm{MAS}$ NMR spectrum of the as-made AlPO-ERI compound.

structure given in Fig. 4, it can be seen that $\mathrm{P}(2)$ is not connected to five-coordinate $\mathrm{Al}$ species, since the $\mathrm{Al}(1)$ atom in the neighboring column is always a tetrahedral $\mathrm{Al}$ species. Thus, $\mathrm{P}(2)$ can be unambiguously associated with the ${ }^{31} \mathrm{P}$ NMR signal at $-32 \mathrm{ppm} . \mathrm{P}(1)$ and $\mathrm{P}(3)$ are connected to the five-coordinate $\mathrm{Al}$ species, located in the six-rings at the top and bottom of the cage, but not to the four-coordinate $\mathrm{Al}(5)$ and $\mathrm{Al}(9)$ resonating at $43 \mathrm{ppm}$. Therefore, they correspond to the two ${ }^{31} \mathrm{P}$ NMR signals around $-18 \mathrm{ppm}$. The $2 \mathrm{D}{ }^{27} \mathrm{Al}-{ }^{31} \mathrm{P}$ $\mathrm{CP} / \mathrm{MAS}$ spectrum indicates that all other phosphorus atoms are connected to both types of $\mathrm{AlO}_{4}$ tetrahedra. In the lower cancrinite cage, $\mathrm{P}(6)$ is bonded to 2 pentacoordinated $\mathrm{Al}(4)$ and $\mathrm{Al}(6)$ species, to $\mathrm{Al}(1)$ in the same cage and to $\mathrm{Al}(9)$ in the cage above (Fig. 4). From the 2D NMR spectrum, $\mathrm{Al}(1)$ and $\mathrm{Al}(9)$ must be tetrahedrally coordinated, which means that the $\mathrm{O} 3 \mathrm{H}$ position is also vacant in the upper cage. These arguments can be continued down the column. This important result demonstrates that $\mathrm{OH}$ groups are ordered along a column (hexagonal prisms alternating with cancrinite cages) of the structure. However, the order is not maintained between the columns and the structure does not possess a long-range ordering.

After calcination, ${ }^{31} \mathrm{P}$ and ${ }^{27} \mathrm{Al}$ NMR spectra of the solid (not shown) are composed of a unique signal at -30 and $35 \mathrm{ppm}$, respectively. In particular, the ${ }^{27} \mathrm{Al}$ 
NMR signal indicates that all aluminum atoms are tetrahedrally coordinated and that extraframework $\mathrm{OH}$ groups have been removed. Both ${ }^{31} \mathrm{P}$ and ${ }^{27} \mathrm{Al} \mathrm{NMR}$ spectra are modified upon rehydration of the calcined solid. The ${ }^{27} \mathrm{Al}$ spectrum is complex and contains many lines between +45 and -50 ppm (Fig. 1). The signals ranging from -15 to $-50 \mathrm{ppm}$ can be unambiguously assigned to octahedrally coordinated $\mathrm{Al}$ species. They result from the modification of the coordination of framework $\mathrm{Al}$ atoms in the presence of water. The intensity of the signal represents approximately one third of the total intensity. The other signals between 5 and $45 \mathrm{ppm}$ correspond to Al tetrahedra. Indeed, the 2D-5Q MAS NMR spectrum (not shown) shows that all aluminum atoms in this region possess an isotropic chemical shift characteristic of tetrahedrally coordinated species. However, some of these species possess very strong quadrupolar coupling constants, probably due to their interaction with non-framework water molecules. The ${ }^{31} \mathrm{P}$ NMR spectrum of the rehydrated compound shows a major line at $-27 \mathrm{ppm}$ along with shoulders at -23.5 and $-30 \mathrm{ppm}$ (Fig. 1). It can be deconvoluted with three Gaussian lines with relative intensities 1:4:4 (Table 3), suggesting the existence of nine crystallographically non-equivalent $\mathrm{P}$ sites in the framework.

The X-ray powder diffraction pattern of the calcined rehydrated aluminophosphate is not very different from that of the as-made solid. This suggests that calcination and subsequent rehydration do not modify the topology of the framework, as it has been observed for other aluminophosphates. Moreover, the hydration process is reversible and both the X-ray powder pattern and NMR spectra of the dehydrated solid are restored upon evacuation at $100{ }^{\circ} \mathrm{C}$. A TG experiment has shown that all water molecules are expelled from the channels at a temperature of ca. $100{ }^{\circ} \mathrm{C}$, with a weight loss corresponding to $21.85 \mathrm{wt} . \%$.

The unit cell of the calcined rehydrated solid is doubled along $c$ but the symmetry is now $P 2(1) / n$ (Table 1), which again leads to nine crystallographically non-equivalent $\mathrm{P}$ and $\mathrm{Al}$ positions, in agreement with NMR data. Three $\mathrm{Al}$ atoms are octahedrally coordinated, also in agreement with ${ }^{27} \mathrm{Al}$ NMR data. These atoms, namely $\mathrm{Al}(1), \mathrm{Al}(2)$ and $\mathrm{Al}(3)$, are the atoms that were tetrahedrally coordinated in the as-made material (Fig. 6). By contrast, all $\mathrm{Al}$ atoms in the six-rings at the top and at the bottom of the cancrinite cage remain

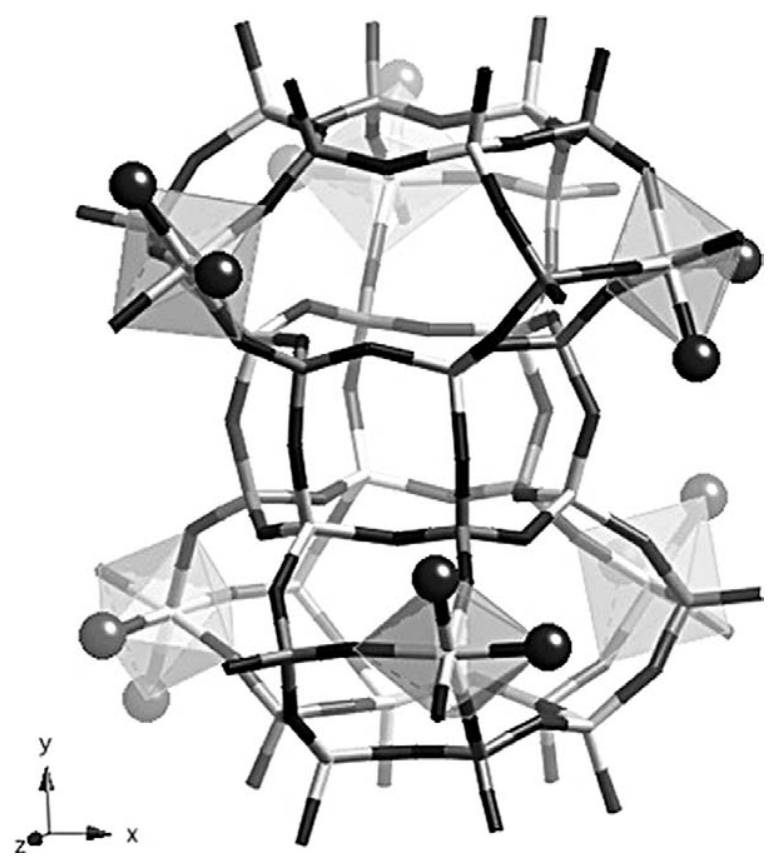

Fig. 6. Structure of the calcined rehydrated solid showing the Al octahedra in the CAN cages. Dark gray: P tetrahedra, light gray: Al polyhedra. Dark spheres represent framework water molecules.

four-coordinated. The attached water molecules $(\mathrm{O} 1 \mathrm{~W}$ to $\mathrm{O} 6 \mathrm{~W}$ ) point into the large ellipsoidal cage and not in the cancrinite cage, as extraframework $\mathrm{OH}$ groups did in the as made compound. One explanation for this could be that the water molecules could not easily enter the cancrinite cages because the $6 \mathrm{MR}$ that are accessible from the large cage are puckered. These six water positions are fully occupied and the three octahedrally coordinated $\mathrm{Al}$ atoms are topologically identical and related by a threefold axis. Despite this, the symmetry of the crystal is monoclinic but only slightly deviates from the hexagonal symmetry. The calcined rehydrated aluminophosphate also contains non-framework water molecules, i.e. molecules that are not directly bonded to framework aluminum atoms. There are 11 additional water molecules per unit cell, and all are located in the large ellipsoidal cage. They are distributed over 14 crystallographic positions, six positions being only half occupied. As mentioned above, cancrinite cages as well as D6R units do not contain any water molecules. The chemical formula of the calcined rehydrated solid is $\left[\mathrm{Al}_{9} \mathrm{P}_{9} \mathrm{O}_{36}\left(\mathrm{H}_{2} \mathrm{O}\right)_{6}\right] \cdot 11 \mathrm{H}_{2} \mathrm{O}$, which corresponds to $21.8 \mathrm{wt} \% \mathrm{H}_{2} \mathrm{O}$, in excellent agreement with the value obtained by thermal analysis. 


\section{Supplementary material available}

The crystallographic data (excluding structure factors) for the two structures have been deposited with the Cambridge Crystallographic Data Center for the as-made structure (CCDC 238862) and the Fachinformationzentrum Karlsruhe for the calcined rehydrated structure (CSD-Nr. 414026). Copies of the data can be obtained, free of charge, on application to CCDC, 12 Union Road, Cambridge CB2 1EZ, UK (e-mail: deposit@ccdc.cam.ac.uk), or Fachinformationzentrum Karlsruhe, Abt. PROKA, 76344 Eggen-SteinLeopoldshafen, Germany (e-mail: crysdata@ fizkarlsruhe.de).

\section{References}

[1] S.T. Wilson, B.M. Lok, C.A. Messina, T.R. Cannan, E.M. Flanigen, J. Am. Chem. Soc. 104 (1982) 1146.

[2] B.M. Lok, C.A. Messina, R.L. Patton, R.T. Gajek, T.R. Cannan, E.M. Flanigen, US Patent 4440 (1984) 871.

[3] B.M. Lok, C.A. Messina, R.L. Patton, R.T. Gajek, T.R. Cannan, E.M. Flanigen, J. Am. Chem. Soc. 106 (1984) 6092.

[4] B.M. Lok, B.K. Marcus, E.M. Flanigen, US Patent 4500 (1985) 651.

[5] S.T. Wilson, E.M. Flanigen, US Patent 4567 (1986) 29.

[6] C.A. Messina, B.M. Lok, E.M. Flanigen, US Patent 4544 (1985) 143.

[7] S.T. Wilson, E.M. Flanigen, in: M.L. Occelli, H.E. Robson (Eds.), Zeolite Synthesis, ACS Symp. Ser. 398, 1989, p. 329.
[8] E.M. Flanigen, B.M. Lok, R.L. Patton, S.T. Wilson, Pure Appl. Chem. 58 (10) (1986) 1351.

[9] J.J. Pluth, J.V. Smith, J.M. Bennett, Acta. Crystallogr. C42 (1986) 283

[10] E.M. Flanigen, B.M. Lok, R.L. Patton, S.T. Wilson, in: Y. Murakami, A. Iijima, W.J. Ward (Eds.), Proc. 7th Int Zeolite Conference, Kodansha, Tokyo, 1986, p. 103.

[11] M.M. Harding, B.M. Kariuki, Acta. Crystallogr. C50 (1994) 852 .

[12] A. Simmen, Ph.D. Thesis, ETH No. 9710, University of Zürich, Switzerland, 1992.

[13] A. Simmen, L.B. McCusker, C. Baerlocher, W.M. Meier, Zeolites 11 (1991) 655.

[14] S.T. Wilson, B.M. Lok, C.A. Messina, E.M. Flanigen, in: D. Olson, A. Bisio (Eds.), Proceedings of the Sixth International Zeolite Conference, Reno, Butterworths, Guilford, UK, 1984, p. 97.

[15] U. Lohse, E. Löffler, K. Kosche, J. Jänchen, B. Parlitz, Zeolites 13 (1993) 549

[16] Q. Gao, S. Li, R. Xu, J. Chem. Soc., Chem. Commun (1994) 1465.

[17] G.M. Sheldrick, SHELXTL PLUS, Program for the Solution of Crystal Structures, University of Göttingen, Germany, 1986.

[18] G.M. Sheldrick, SHELX 93, Program for the Refinement of Crystal Structures, University of Göttingen, Germany, 1993.

[19] A. Medek, J.S. Harwood, L. Frydman, J. Am. Chem. Soc. 117 (1995) 12779.

[20] C. Fernandez, J.P. Amoureux, J. Phys. Lett. 242 (1995) 449.

[21] D. Marion, K. Würthrich, Biochem. Biophys. Res. Commun. 113 (1983) 967.

[22] G. Drobny, A. Pines, S. Sinton, D. Weitekamp, D. Wemmer, Symp. Faraday Div. Chem. Soc. 13 (1979) 49.

[23] C.S. Blackwell, R.L. Patton, J. Phys. Chem. 88 (1984) 6135. 